\title{
Aktivitas Antibakteri Senyawa Turunan Oleanan dari Kayu Akar Pterospermum Subpeltatum
}

\author{
Pince Salempa ${ }^{1 *}$, Alfian Noor ${ }^{2)}$, Nunuk Hariani²), dan Tjodi Harlim²) \\ 1)Jurusan Kimia, Fakultas Matematika Ilmu Pengetahuan Alam, Universitas Negeri Makassar \\ 2)Jurusan Kimia, Fakultas Matematika IImu Pengetahuan Alam, Universitas Hasanuddin, Makassar
}

Diterima 04-10-2009 Diterima 06-05-2010

\begin{abstract}
A triterpenoid derivative compound, oleane-12-en-2,3,23-triol-28-oat, from chloroform fraction of root wood of Pterospermum subpeltatum C. B. Rob (Sterculiaceae) was identified using IR, ${ }^{1} \mathrm{H}$ dan ${ }^{13} \mathrm{C}$ NMR data. The compound has shown toxicity against Artemia salina, $\mathrm{LC}_{50}$ of $46.06 \mu \mathrm{g} / \mathrm{mL}$, and antibacterial potential upon Shigella boydii and Staphylococcus aureus with inhibition zones of 8.3 and $9.8 \mathrm{~mm}$ respectively.
\end{abstract}

Keywords: antibacterial, A. salina, Pterospermum subpeltatum, oleane-12-en-2,3,23-triol-28-oate

\section{PENDAHULUAN}

Kondisi kebersihan yang buruk dan cuaca yang sering ditandai dengan sangat tingginya temperatur dan kelembaban dapat menyebabkan infeksi pada luka. Hal tersebut pada umumnya terjadi di negara tropik yang sedang berkembang. Terapi dengan antibiotik sintetik tidak selalu bisa dilakukan karena biaya yang mahal. Untuk mengatasi masalah ini masyarakat menggunakan tumbuhan sebagai obat tradisional, walaupun tanpa dukungan ilmiah.

Tumbuhan Pterospermum yang termasuk dalam famili Sterculiaceae secara luas telah dimanfaatkan sebagai obat tradisional oleh masyarakat khususnya di Sulawesi Tengah menggunakan daun $P$. acerifolium yang telah dilayukan di atas api dapat menghilangkan gatal pada kaki akibat terbenam di dalam lumpur (Kruit et al., dalam Heyne, 1987). Kulit batang $P$. javanicum digunakan sebagai obat disentri, sakit gigi, bisul dan keseleo. Daun $P$. diversifolium dikenal sebagai obat gatal dan kulit akar dari tumbuhan ini digunakan sebagai racun ikan (Ogata et al., 1995).

Camporese (2003) melaporkan tentang aktivitas antibakteri dari salah satu spesies tumbuhan famili Sterculiaceae (Guazuma ulmifolia). Ekstrak heksan kulit batang tumbuhan tersebut dapat menghambat pertumbuhan bakteri E. coli, sedangkan ekstrak metanol menghambat pertumbuhan Pseudomonas aeruginosa. Reid et al., (2005), mempelajari aktivitas antibakteri berbagai ekstrak Sterculiaceae lainnya seperti spesies Cola greenwayidan melaporkan bahwa fraksi etil asetat aktif menghambat pertumbuhan bakteri Klebsiella pneumoniae dan Staphylococcus aureus.

Penelusuran pustaka memperlihatkan belum ada laporan berkenaan dengan kajian senyawa bioaktif kayu akar tumbuhan tersebut. Pada penelitian ini dilaporkan bioaktivitas dan isolasi serta penentuan struktur olean12-en-2,3,23-triol-28-oat dari fraksi kloroform kayu akar Pterospermum subpeltatum C.B.Rob. Struktur molekul senyawa tersebut ditetapkan berdasarkan hasil interpretasi data spektroskopi yang meliputi IR, ${ }^{1} \mathrm{H}$, dan ${ }^{13} \mathrm{C}$ NMR termasuk NMR $2 \mathrm{D}$ (HMQC, HMBC dan COSY).

\section{BAHAN DAN METODE}

Peralatan. Titik leleh ditentukan dengan "micro melting point apparatus" Spektrum inframerah diperoleh dengan spektrofotometer Shimadzu LC-9A FT-IR, sedangkan ${ }^{1} \mathrm{H}(500 \mathrm{MHz})$ dan ${ }^{13} \mathrm{C}(125 \mathrm{MHz}) \mathrm{NMR}$ ditentukan dengan spektrofotometer JeolECA 500 serta pelarut terdeuterasi sebagai standar. Kromatografi kolom vakum menggunakan Si-gel $60 \mathrm{GF}_{254}$ (Merck), kromatografi kolom tekan dengan Si-gel Merck 60 (230400 mesh) kromatografi kolom gravitasi (KKG) dengan Si-gel Merck 60 (35-70 mesh) dan analisis kromatografi lapis tipis (KLT) menggunakan plat berlapis Si-gel Merck Kieselgel 60 F254.

\footnotetext{
*Telp: +6281242824334

Email: nuklir@indosat.net.id
} 
Bahan Tumbuhan. Bahan tumbuhan yang digunakan adalah kayu akar Pterospermum subpeltatum C.B.Rob, diperoleh dari kabupaten Mamuju Sulawesi Barat dan telah dideterminasi di Herbarium Bogoriense, Pusat Penelitian dan Pengembangan Biologi, LIPI Bogor.

Ekstraksi dan Isolasi. Sebanyak $10 \mathrm{~kg}$ berat kering kayu akar Pterospermum subpeltatum C.B.Rob dihaluskan lalu dimaserasi dengan metanol selama 1x24 jam beberapa kali. Maserat yang diperoleh dievaporasi sampai diperoleh maserat kental yang diperoleh sebanyak $3 \mathrm{~L}$ dengan berat kering $1,047 \mathrm{~kg}$. Selanjutnya maserat tersebut dipartisi dengan pelarut n-heksan, kloroform dan etil asetat dengan berat masing-masing 43,53 g; 35,7 g dan 17,12 g. Fraksi kloroform $(35,7 \mathrm{~kg})$ difraksinasi dengan kromatografi kolom vakum (KKV) dengan eluen $n$ - heksan, etil asetat:n-heksan, etil asetat, aseton:etil asetat, aseton dan metanol dengan meningkatkan kepolarannya yang menghasilkan delapan fraksi utama. Fraksi keempat dari hasil KKV (470 mg) dipisahkan lebih lanjut dengan kromatografi kolom tekan (KKT) dengan eluen yang sama seperti proses KKV di atas diperoleh isolat berwarna putih. Selanjutnya dilakukan kristalisasi dengan pelarut kloroform dan aseton sehingga diperoleh kristal berwarna putih seberat 120 mg yang kemudian direkristalisasi menghasilkan kristal putih sebanyak $15,9 \mathrm{mg}$.

Uji biologis. Uji toksisitas dilakukan dengan menggunakan benur udang Artemia salina sesuai dengan metode Meyer et al., (1982) dan uji anti bakteri (Bakteri uji, Staphylococcus aureus ATCC 25923 dan Shigella boydii) dilakukan dengan menggunakan metode Difusi Agar (Djide, N \& Sartini, 2008). Senyawa yang diperoleh sebagai serbuk berwarna putih : t.l. $289-290^{\circ} \mathrm{C}$ IR ( KBr) ím max $: 3456$; 3350; 3298; 2943; 2904; 2879; 1693; 1462; 1386; 1271; $1049 \mathrm{~cm}^{-1} ;{ }^{1} \mathrm{H}$ NMR, ${ }^{13} \mathrm{C}-\mathrm{NMR}$, cosy dan HMBC ditunjukkan dalam Tabel 1.

\section{HASIL DAN PEMBAHASAN}

Senyawa diperoleh sebagai serbuk putih, t.I. 289$290^{\circ} \mathrm{C}$ dengan spektrum UV pada panjang gelombang maksimum pada $205 \mathrm{~nm}$. Data spektrum IR $(\mathrm{KBr})$ yang memperlihatkan pita serapan pada bilangan gelombang; 3456; 3350; $3298 \mathrm{~cm}^{-1}$ yang mengindikasikan adanya gugus $\mathrm{OH}$ bebas yang didukung oleh adanya puncak serapan pada $1049 \mathrm{~cm}$ untuk vibrasi ulur C-O. Serapan pada 2943; 2904; 2979 $\mathrm{cm}^{-1}$ untuk $\mathrm{C}-\mathrm{H}$ alifatik yang didukung adanya serapan pada $1462,04 \mathrm{~cm}^{-1}\left(\mathrm{CH}_{2}\right)$ dan $1836 \mathrm{~cm}^{-1}\left(\mathrm{CH}_{3}\right)$. Adanya gugus $\mathrm{C}=\mathrm{O}$ karboksilat pada $1693 \mathrm{~cm}^{-1}$ didukung dengan serapan C-O pada daerah $1271 \mathrm{~cm}^{-1}$.

Analisis data spektroskopi ${ }^{1} \mathrm{H}-\mathrm{NMR}$ memperlihatkan sinyal khas, di antaranya: pada daerah ä 5,17 ppm $(\mathrm{H}-12,1 \mathrm{H}, \mathrm{t}, \mathrm{J}=3,05 \mathrm{~Hz})$ yang menunjukkan suatu proton alkena; pada ä 3,47 ppm $(\mathrm{H}-2 ; 1 \mathrm{H} ; \mathrm{m})$ dan ä 3,16 ppm $(\mathrm{H}-3,1 \mathrm{H}, \mathrm{d}, \mathrm{J}=9,2 \mathrm{~Hz})$; yang menunjukkan proton metin tersubstitusi gugus hidroksil; dan 6 sinyal pada ä 0,53 ppm (H-24); ä 0,91 ppm (H25); ä 0,70 ppm H-26); ä 1,09 ppm (H-27); ä 0,87 ppm $(\mathrm{H}-29)$ dan ä 0,87 ppm ( $\mathrm{H}-30)$ yang menunjukkan proton metil yang terikat pada karbon jenuh. Sinyal-sinyal proton tersebut mengindikasikan suatu kerangka triterpen turunan olean-12-en yang tersubstitusi gugus hidroksil.

Analisis data spektrum ${ }^{13} \mathrm{C}$-NMR memperlihatkan 30 sinyal yang mewakili 30 karbon, yang meliputi satu karbonil (C-28) asam karboksilat pada ä 178,6; dua karbon alkena pada ä 143,9 (C-13) dan 121,5 (C-12) ppm; tiga oksi karbon pada 75,5 (C-3); 67,4 (C-2) dan 63,8 (C-23) ppm; dan dengan dukungan DEPT-135 memperlihatkan enam sinyal metil (C-24; C-25; C-26; C-27; C-29; C-30); sepuluh sinyal metilen (C-1; C-6; C7; C-11; C-15; C-16; C-19; C-21; C-22; C-23) dan enam sinyal metin (C-2; C-3; C-5; C-9; C-12; C-18). Dari data tersebut dapat diketahui adanya 8 karbon kuarterner yaitu C-4; C-10; C-8; C-13; C-14; C-17; C-20; dan C28. Tiga puluh sinyal karbon tersebut membentuk kerangka triterpen jenis olean-12-en. Dari data korelasi HMBC (Tabel 1) antara proton $\left({ }^{1} \mathrm{H}\right)$ dan $\left({ }^{13} \mathrm{C}\right)$ dapat disimpulkan bahwa senyawa adalah olean-12-en2,3,23-triol-28-oat, seperti pada Gambar 1.

Data tersebut juga dibandingkan dengan data senyawa olean-12-2,3,23-triol-28-oat (asam arjunolat) yang pernah dilaporkan Collins et al., (1992) seperti yang terlihat pada Tabel 1. Dari perbandingan tersebut lebih memastikan bahwa senyawa adalah olean-12-en2,3,23-triol-28-oat.

Uji toksisitas terhadap benur udang $A$. salina memperlihatkan nilai $L_{50}=46,06 \mathrm{~kg} / \mathrm{mL}$ dan uji anti bakteri menunjukkan daya hambat $8,3 \mathrm{~mm}$ terhadap Shigella boydii dan 9,8 mm terhadap Staphylococcus aureus sedangkan tetrasiklin sebagai kontrol menunjukkan daya hambat masing-masing $13,5 \mathrm{~mm}$ dan 23,08 $\mathrm{mm}$ terhadap Shigella boydii dan Staphylococcus aureus. Adanya perbedaan daya 
Tabel 1. Data Spektrum ${ }^{1} \mathrm{H},{ }^{13} \mathrm{C}$ dan $2 \mathrm{D}$ NMR Senyawa

\begin{tabular}{|c|c|c|c|c|c|}
\hline No & $\delta_{\mathrm{H}}$ (multi. $J$ dalam Hz) & $\delta_{\mathrm{C}}$ & $\begin{array}{l}\mathrm{COSY} \\
\mathrm{H} \Leftrightarrow \mathrm{H}\end{array}$ & $\begin{array}{l}\mathrm{HMBC} \\
\mathrm{C} \Leftrightarrow \mathrm{H}\end{array}$ & Asam Arjunolat \\
\hline 1 & $\begin{array}{l}1.72(1 \mathrm{H}, d t, J=4.3 \& 12.85 \mathrm{~Hz}) \\
0.72(1 \mathrm{H}, m)\end{array}$ & 46,7 & & - & 46,2 \\
\hline 2 & $3.47(1 \mathrm{H}, m)$ & 67,4 & 3 & - & 68,0 \\
\hline 3 & $3.16(1 \mathrm{H}, d, J=9.2 \mathrm{~Hz})$ & 75,5 & 2 & 24 & 78,8 \\
\hline 4 & - & 42,5 & - & 24 & 42,7 \\
\hline 5 & $1.21(1 \mathrm{H}, m)$ & 46,0 & & 24 & 48,0 \\
\hline 6 & $\begin{array}{l}1,38(1 \mathrm{H}, m) \\
1,20(1 \mathrm{H}, m)\end{array}$ & 17,5 & & - & 18,1 \\
\hline 7 & $\begin{array}{l}1.45(1 \mathrm{H}, m) \\
1.18(1 \mathrm{H}, m)\end{array}$ & 31,9 & & 26 & 32,1 \\
\hline 8 & - & 38,7 & - & - & 39,2 \\
\hline 9 & $1.54(1 \mathrm{H}, d d, J=7.35 \& 10.4 \mathrm{~Hz})$ & 47,1 & & $10,11,25,26$ & 48,0 \\
\hline 10 & - & 37,4 & - & 10,25 & 38,0 \\
\hline 11 & $1.83(2 \mathrm{H}, m)$ & 23,1 & 12 & - & 23,4 \\
\hline 12 & $5.17(1 \mathrm{H}, t, J=3.05 \mathrm{~Hz})$ & 121,5 & 11 & - & 122,0 \\
\hline 13 & - & 144,0 & - & 27 & 143,8 \\
\hline 14 & - & 41,4 & - & - & 41,6 \\
\hline 15 & $\begin{array}{l}1.02(1 \mathrm{H}, m) \\
0.96(1 \mathrm{H}, m)\end{array}$ & 27,2 & & 27 & 27,6 \\
\hline 16 & $\begin{array}{l}1.91(1 \mathrm{H}, t d, J=3.65 \& 13.45 \mathrm{~Hz}) \\
1.48(1 \mathrm{H}, m)\end{array}$ & 22,6 & & - & 23,0 \\
\hline 17 & - & 45,5 & - & - & 46,6 \\
\hline 18 & $2.72(1 \mathrm{H}, d d, J=4.3 \& 14.05 \mathrm{~Hz})$ & 40,8 & & - & 41,2 \\
\hline $\begin{array}{l}\text { ss } \\
19\end{array}$ & $\begin{array}{l}1.60(1 \mathrm{H}, m) \\
1.03(1 \mathrm{H}, m)\end{array}$ & 45,7 & & 29 & 45,8 \\
\hline 20 & - & 30,5 & - & 29,30 & 30,6 \\
\hline 21 & $\begin{array}{l}1.32(1 \mathrm{H}, t d, J=4.3 \& 14.5 \mathrm{~Hz}) \\
1.11(1 \mathrm{H}, m)\end{array}$ & 33,3 & & 30 & 33,8 \\
\hline 22 & $\begin{array}{l}1.47(1 \mathrm{H}, m) \\
1.42(1 \mathrm{H}, m)\end{array}$ & 32,1 & & - & 32,3 \\
\hline 23 & $\begin{array}{l}3.29(1 \mathrm{H}, d d, J=3.7 \& 7.3 \mathrm{~Hz}) \\
3.03(1 \mathrm{H}, d d, J=3.7 \& 7.3 \mathrm{~Hz})\end{array}$ & 63,8 & - & 24 & 68,6 \\
\hline 24 & $0.53(3 \mathrm{H}, \mathrm{s})$ & 13,8 & - & $3,4,23$ & 13,2 \\
\hline 25 & $0.91(3 \mathrm{H}, s)$ & 16,8 & - & 10 & 16,8 \\
\hline 26 & $0.70(3 \mathrm{H}, s)$ & 16,9 & - & $7,8,14$ & 17,0 \\
\hline 27 & 1. $09(3 \mathrm{H}, s)$ & 25,7 & - & $8,13,14$ & 26,1 \\
\hline 28 & - & 178,7 & - & - & 178,3 \\
\hline 29 & $0.87(3 \mathrm{H}, s)$ & 32,9 & - & 20,17 & 33,1 \\
\hline 30 & $0.87(3 \mathrm{H}, \mathrm{s})$ & 23,4 & - & 20 & 23,6 \\
\hline
\end{tabular}

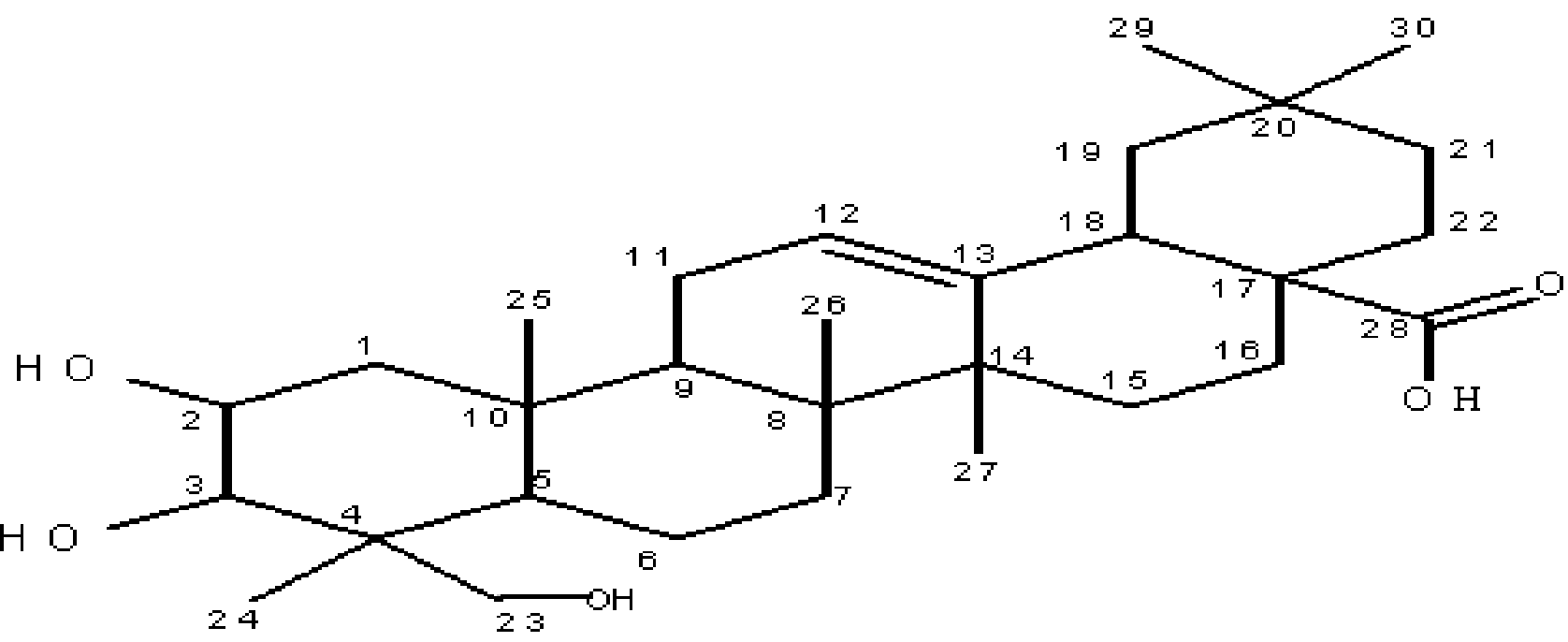

Gambar 1. Senyawa olean-12-en-2,3,23-triol-28-oat 
hambat antara kedua bakteri tersebut dapat disebabkan karena perbedaan kepekaan atau resistensi mikroorganisme terhadap senyawa yang diujikan. Menurut Jawetz et al., (2001) gangguan terhadap sintesis dinding sel, fungsi membran sel, sintesis protein dan asam nukleat dapat menyebabkan terhambatnya pertumbuhan bakteri.

\section{KESIMPULAN}

Senyawa olean-12-en-2,3,23-triol-28-oat telah ditemukan untuk pertama kalinya dari $P$. subpeltatum dan berpotensi sebagai anti bakteri dengan daya hambat 8,3 mm terhadap Shigella boydii dan 9,8 mm terhadap Staphylococcus aureus serta cukup aktif terhadap Artemia salina dengan $\mathrm{LC}_{50}: 46,06 \mathrm{ig} / \mathrm{ml}$.

\section{UCAPAN TERIMA KASIH}

Direktur Jenderal Pendidikan Tinggi Depdiknas atas pemberian beasiswa BPPS, Herbarium Bogoriense, Pusat Penelitian dan Pengembangan
Biologi dan Pusat Penelitian Kimia LIPI yang telah mengidentifikasi bahan tumbuhan dan melakukan pengukuran spektrum ${ }^{1} \mathrm{H}$ dan ${ }^{13} \mathrm{C}-\mathrm{NMR}$.

\section{DAFTAR PUSTAKA}

Camporese, A., Balick, M.J. F., Arvigo, R., Esposito, R.G., Marsellino, N., De Simone, F. \& Tubaro, A. 2003. Screening of anti-bacterial of medicinal plants from Belize (Central America). Ethnopharmacology 87: 103-107.

Collins, D.J., Pilotti, C.A. \& Wallis, A.F.A. 1992, Triterpene acids from Some Papua New Guinea Terminalia spesies, Phytochemistry 31(3): 881-884.

Djide, N. \& Sartini. 2008. Analisis Mikrobiologi Farmasi. Fakultas Farmasi UNHAS Makassar.

Heyne, K. 1987. Tumbuhan Berguna Indonesia III. Jakarta: Badan Litbang Kehutanan,

Jawetz, E., Melnick. \& Adelberg. 2001. Mikrobiologi Kedokteran, edisi 20, Buku Kedokteran, EGC, Jakarta.

Meyer, B.N., Ferrigny, N.R., Putnam, J.E., Jacobbsen, L.B., Nicols, D.E., M.c. \& Laughlin, J.L. 1982. Brine shrimp, A. covenient general bioassay for active plant Constituent. Medical Plant Research 45: 31-34.

Ogata, Y. (Committe Members). 1995. Indeks Tumbuhtumbuhan Obat di Indonesia. PT. Esai Indonesia Edisi 2: 75-79.

Reid, K.A., Jager, A.K., Light, M.E., Mulholland, D.A. \& Van Staden, J. 2005. Phytochemical and pharmalogical screening of Sterculiaceae Species and Isolation of Antibacterial compounds. Etnopharmacologi 97: 285-291. 